\title{
A ESTÉTICA RICA E A ESTÉTICA POBRE DOS PROFESSORES FRANCESES *
}

\section{GILDA DE MELLO E SOUZA}

O que me traz aqui, na presença de vocês, é na verdade um paradoxo. Pois, não me sentindo a pessoa mais indicada para proferir a aula inaugural dos nossos cursos deste ano, decidi dar uma aula terminal. $\mathrm{E}$ isso em mais de um sentido. Não apenas porque esta é a última vez que eu falo no Departamento como professor regular de seus quadros; mas porque o que vou dizer não representa uma abertura, e sim um fechamento; o arremate num período arcaico e talvez artesanal da nossa história, porque sem especializações; período de que fui testemunha, protagonista, e sou hoje remanescente.

Será por isso uma dissertação voltada para o passado e evocará poucos nomes - três para ser exata. Nem todos estão ligados diretamente à filosofia; mas estão profundamente confundidos com uma primeira idade universitária, com certo momento da vida cultural em São Paulo. E como aqueles que na minha geração se interessaram pelos problemas de arte devem muito a Jean Mauguié, Claude Levi-Strauss e Roger Bastide, dedico aos três professores a homenagem desta evocação.

Contudo não irei focalizá-los através dos livros, ou da atividade intelectual que desenvolveram posteriormente. Mas através dos escritos da época, artigos e ensaios às vezes de circunstância que, surgidos de 1934 a 1940 e poucos, em jornais ou em publicações de difícil acesso, permanecem esparsos e em geral desconhecidos. Não escolhi essa abordagem por coquetterie; mas para dar uma idéia da atmosfera intelectual em que vivíamos e a que iria se referir, bem mais tarde e não sem ironia, aquele que se tornou o mais célebre dos três, Levi-Strauss, em Tristes Tropiques.

O nome de Jean Maugüé não deve significar nada para a maioria dos mais jovens que me estão ouvindo. No entanto, para os alunos que tiveram a ventura de assistir às suas aulas entre 1935 e 1944,

- Aula inaugural dos Cursos de 1973 do Departamento de Filosofia, da Faculdade de Filosofia, Letras e Ciências Humanas da Universidade de São Paulo. 
o seu nome evoca todo um folclore. Maugüé não era apenas um professor - era uma maneira de andar e de falar, que alguns de nós imitavam afetuosamente com perfeição; era um modo de abordar os assuntos, hesitando, como quem ainda decidiu por onde começar e não sabe ao certo o que tem a dizer; e por isso se perde em atalhos, retrocede, retoma um pensamento que deixara incompleto, segue as idéias ao sabor das associações. Mas esse era o momento preparatório no qual, como um acrobata, esquentava os músculos; depois, alçava vôo e, então, era inigualável.

A impressão e a marca que deixou em nós foram extraordinárias e, mesmo agora, depois que o correr dos anos nos ofereceu tantas oportunidades de comparação, continuamos considerando-o como um dos maiores professores que já conhecemos. Da mesma geração que Merleau-Ponty e Sartre — de quem é amigo até hoje — não fez carreira universitária. Depois do período brasileiro, que permaneceu na sua memória como uma espécie de idade de ouro, alistou-se, fez a guerra desde o Norte da África com Delattre de Tassigny, foi condecorado por bravura, ensaiou uma aventura gorada na diplomacia e voltou a ser professor de liceu, cargo onde se encontra até o momento.

Naquele tempo era o único professor de filosofia e se encarregava da Ética, da História da Filosofia (Antiga e Moderna), da Psicologia. Suas aulas eram, acima de tudo, uma longa meditação que tomava freqüentemente como temas a arte e a política. A familiaridade com Racine e os grandes romancistas franceses do Século 19 desenvolveram nele o gosto pela análise das paixões do amor, a que se entregava com a lucidez e o pessimismo de um Benjamin Constant. Entre os filósofos, amava sobretudo Platão e Spinoza, divertindo-se muito com o bom senso de Aristóteles, a quem chamava, fazendo pilhéria, de "um garotinho muito inteligente... tão inteligente como o meu colega Levi-Strauss..." E como todos de sua geração, Maugüé havia recebido o impacto profundo de Marx e de Freud. A influência de Alain, de quem fora aluno, revela-se no desprezo pela vida universitária e na habilidade de desentranhar a filosofia do acontecimento, quotidiano, da notícia de jornal. Foi com Jean Mauguié que, em 1940, por ocasião da grande exposição de pintura francesa, aprendemos a olhar um quadro.

Apesar de ser um escritor admirável - como atestam os poucos escritos que deixou no Brasil - não escreveu nenhum livro. Em outubro de 1939, por ocasião da morte de Freud, publicou em $O$ Estado de São Paulo um artigo penetrante e emocionado, que no ano seguinte apareceu desenvolvido na Revista do Brasil. Mas são suas análises sobre a pintura, que vão, nesta palestra, reter a nossa atenção. 
A primeira, é uma conferência, A Pintura Moderna, pronunciada em 1938, no $2 .^{\circ}$ Salão de Maio e publicada pela Revista do Arquivo Municipal; a segunda, Os Problemas da Pintura Moderna, está incluída no catálogo da exposição de pintura francesa de 1940.

Lendo hoje esses dois ensaios, vemos que o que Jean Maugüé procurava nos quadros não era a pintura, - como de certo modo já fazia Levi-Strauss, - mas o eco de uma relação harmoniosa do homem com a natureza. E não era certamente a pintura moderna, como erroneamente poderíamos supor pelos seus títulos, pois com suas estridências, sua fuga ao real, amor pela pesquisa e mal-estar, ela o perturbava muito. As suas análises voltam-se sempre para a pintura holandesa do Século 17, que, tranquiila e equilibrada, é o seu ponto de referência obsessivo. "A pintura holandesa" - diz ele - "dá-nos no Século 17 uma lição de unidade. Não essa unidade de fato, que o recuo no passado espontaneamente realiza, e que se chama caráter de uma época, mas essa unidade voluntária, dos temas e dos estilos. Na paisagem, por exemplo, os pintores parecem ter-se consagrado a pôr em relevo as idéias gerais da natureza holandesa. Tentaram apreender os grandes aspectos permanentes desse país plano, de grandes prados, sempre molhado, semifundido às águas estagnantes e chuvas do céu, aos rios e ao mar, em que o próprio sol é úmido. Sua pintura distribui-se por estações e no interior destas por motivos vastos: a duna, o bosque, a planície, as pastagens e finalmente as cidades. Quanto ao que o homem soube acrescentar à natureza, quanto às modificações humanas das paisagens naturais, ressaltam esses poucos instrumentos muito simples e vulgares, bem próximos ainda das próprias forças da água, da terra e do vento, esses instrumentos, tão serenos e tão evidentes, que parecem ter sido produzidos pela própria paisagem: moinhos, velas dos barcos, cercas junto às quais pastam rebanhos." Ora, essa unidade da pintura holandesa não foi construída pelos pintores, por Ruysdaël, Potter, Cuyp, mas foi obra coletiva do povo, deriva do seu esforço de adaptação "às condições naturais, em vista de construir um habitat". Por isso a pintura holandesa, objetiva e naturalista, é uma pintura patriótica e, acima de tudo, pensada - "exatamente como uma paisagem é pensada, quando remodelada pelo homem, para que o homem possa trabalhar dentro dela."

Não é de estranhar que, ao lado dessa pintura, que se impôs como uma segunda natureza, o impressionismo exprima um movimento de espírito oposto, uma espécie de "incapacidade de pensar as grandes idéias gerais da natureza." Ao mergulhar no particular, no único, no fugidio, na pesquisa do instante, a pintura - neste universo heraclitiano - da mesma forma que o pensamento - diz Maugüé 
- se dissolve. E se no fim do Século 19 os pintores procuram tanto a natureza singular, é porque já se haviam afastado da natureza em geral, "dessa grande harmonia que ela estabelece com o trabalho humano."

Assim, a história da pintura nos últimos cinqüenta anos (oitenta...) é a história da repercussão, na arte pictural, de uma imensa revolução. Da revolução industrial, que reinventou a natureza, rasgou a paisagem com as fábricas, deu nascimento aos subúrbios, multiplicou as zonas escalavradas; mudança que exigiu do olho humano uma acomodação difícil às novas condições de velocidade; que impediu, com a mobilidade social das classes, o estabelecimento de um estilo de vida e de uma nova síntese. "O mundo do Século 20" — suspira ele nostálgico - "não é mais um mundo homogêneo como a Holanda do Século 17."

Esse milagre da paisagem holandesa, onde o pintor vive no mesmo ritmo que os elementos naturais, Maugüé só o reencontra, no Século 19, em Corot. Só nele descobre o pintor da "cadência um pouco lenta, mas profunda das coisas", do "movimento autêntico dos rios, das árvores e dos céus." A seu ver, nem mesmo Cézanne conseguiu desembaraçar a pintura dos sofismas do impressionismo. Tem uma mão operária, uma inteligência lógica, mas falta-lhe sensibilidade:

"Apesar da admiração que devemos a esse grande nome, é preciso acrescentar que a solução de Cézanne honra mais seu espírito que sua sensibilidade. Este construtor pouco se preocupou com o que podia pensar das massas coloridas que pintava. Fixou a natureza com o mesmo olhinho redondo com que nos observa de seu retrato: com uma espécie de autoridade policial, mas sem paixão nem ternura. Debaixo do amplo chapéu-coco que lhe dá o ar tão típico do pequeno-burguês francês, jamais rolaram meditações metafísicas muito vastas. Toda a sua filosofia parece resumir-se em pintar bem, e quanto ao resto, a desprezar a inquietação dos homens. Esta escolha seria respeitável se, uma vez instalado na obra, nos provasse que era capaz de sair dela; isso ele nunca fez. É por essa razão que os pintores o têm na conta de Cézanne o inigualável; mas talvez seja permitido às sensibilidades mais literárias, que restrinjam as suas virtudes a virtudes mais propriamente picturais. Qualquer coisa de duro e de impenetrável nos adverte que em suas telas jamais circulou o movimento de uma grande alma."

O que não encontrava em Cézanne - nesta análise que nos revela Jean Maugüé de corpo inteiro, com o seu amor pelo paradoxo e a coragem das suas paixões arbitrárias - também não vai encontrar no cubismo, que, segundo ele, limitou-se "a sutilizar a pintura de Cézanne, enervando-a de intelectualismo". A nova relação verda- 
deira entre a natureza e o homem, nos tempos modernos, Maugüé divisa apenas em três pintores: Vlaminck, Utrillo e Van Gogh. E admirável, por exemplo, o que diz deste último:

"Como ninguém mais ele sentiu a tragédia de uma estrada, perdendo-se nas fronteiras do céu. Esse holandês do Brabante, nascido numa região plana onde o viajante sente de todos os lados o apelo dos caminhos, que passou por tantos lugares, antes de fixar-se num canto da França, onde vai, aliás, encontrar a loucura, é talvez com Verhaeren, o artista que compreendeu, com mais profundidade, o que significava, para um coração inquieto, a grande partida solitária pela estrada. Suas paisagens não são apenas aspectos da natureza, são sobretudo testemunhos de uma sensibilidade. Nos seus quadros o movimento que nos faz partir, não é o próprio movimento das coisas, mas o impulso de um viajante miserável. Pois o que vamos encontrar ao longo do caminho é o sofrimento dos homens, nos campos cheios de trabalho, nas casas cheias de fadiga e de refeições parcas. A cor, por sua vez, intervém para completar a impressão do quadro. E ingrata, de um amarelo soturno e dividido, com vermelhos pálidos e verdes sem doçura. Quem poderia encontrar as cores nobres e pacificadoras de outrora, o colorido de Rousseau ou de Corot, nessas paisagens torturadas, nesses campos destruídos pelo sol e atormentados por uma espécie de revolta social? São as cores que o pobre olhar do camponês e do operário enxergam e para esses deserdados, há muito que o manto de Salomão se retirou da natureza."

Mas deixemos Jean Maugüé por enquanto.

Claude Levi-Strauss não precisa de apresentação; a partir da estadia no Brasil tem início a carreira fulgurante que o vai transformar num dos grandes pensadores do seu tempo. Quando foi nosso professor tinha vinte e sete anos, acabava de descobrir a etnografia, era tímido, e odiava Durkheim. Não vou referir-me aos seus livros; nessa época ainda não tinha visitado os bororos e acho que não tinha escrito quase nada. Mas ligara-se de maneira eficiente à vida intelectual da cidade, ajudando, por exemplo, Mário de Andrade a organizar, no Departamento de Cultura, a Sociedade de Etnologia e Folclore. *

É em 1935, na altura de novembro, que surge na Revista do Arquivo um pequeno artigo, "O Cubismo e a Vida Quotidiana", que fora antecedida de pouco por outra análise aparecida no segundo número da Revista Contemporânea, também sobre a pintura moderna.

- A essa sociedade, Dina Dreyfüs, sua mulher de então, dedicou o melhor de seu esforço. 
O amor de Levi-Strauss pela pintura data, pois, da mocidade e deve ter sido herdado do pai, que era pintor. E um afeto que permanece presente em toda a sua obra, que ressurge no Pensamento Selvagem, na Introdução do Cru e do Cozido, na admirável série de entrevistas com Georges Charbonnier e revela nele uma afinidade mais sincera que a afinidade ostentada pela música.

$\mathrm{O}$ escrito da Revista do Arquivo inicia-se, de maneira sintomática, com uma citação de Baudelaire. Mas a referência ao grande crítico do Século 19 não impede a compreensão profunda que Levi-Strauss manifesta pelo movimento - que focaliza como um fenômeno paradoxal. Pois tendo nascido e se desenvolvido sob o signo do divórcio entre a arte e o público, o cubismo termina penetrando as formas mais pobres e mais utilitárias da expressão. Em vez de fixar a sua análise nos grandes nomes como Picasso, Braque, Gris, Léger, Delaunnay, Duchamp, Levi-Strauss prefere mostrar como o cubismo foi uma aventura estética que modificou a visão do mundo - não apenas a visão do esteta, mas a do homem comum, do homem da rua. Prefere mostrar como penetrou de maneira lenta e insidiosa em nossa vida, não através dos quadros, mas dos objetos feitos em série, dos cartazes, da decoração dos cafés - com seus vidros foscos e tubos cromados; dos manequins dos grandes magasins - estilizados, pintados de cores irreais e tendo por único objetivo pôr em relevo a mercadoria; da arrumação das vitrinas que abandonam o acúmulo tradicional das peças, para destacar o objeto isolado.

O cubismo revela, desse modo, que a decoração devia ser feita, não por soma, mas por subtração. Que "um só chapeu, duas ou três garrafas, engenhosamente iluminadas, realçarão melhor o valor intrínseco do objeto." Que na publicidade, é mais eficiente a apresentação simples e direta da mercadoria: o copo de leite "sozinho, monumental, comove apenas pela força da arquitetura interior, das cores, das linhas, dos reflexos, dos contornos".

Esta percepção objetiva da pintura como uma "justaposição de formas, de contornos, de superfícies, de sombra e luz, de manchas coloridas", que o artista dispõe e transforma a seu gosto, revela em Levi-Strauss a influência marcada da teorização de Fernand Léger, em livros como Função da Pintura e em obras como o seu admirável filme de arte, Ballet Mecânico. Revela a aceitação de uma estética do geométrico e do especificamente pictural - como a da Bauhaus - que, libertando-se da representatividade, já está aceitando a beleza das formas puras e das cores primárias, sem o recurso do claro-escuro. 
Se nos detivermos agora, um momento, em nossa análise, para comparar as posições recíprocas de Jean Maugüé e Claude Levi-Strauss em relação à pintura - no período de mocidade - veremos que elas definem uma oposição muito nítida:

o primeiro vê o quadro como manifestação dos aspectos permanentes da natureza e louva a pintura na medida em que, como arte realista, traduz a adequação entre o ritmo da natureza e o ritmo do trabalho humano;

o segundo vê o quadro (ou o objeto artístico feito em série), como uma manifestação dos aspectos permanentes da pintura e louva esta última, na medida em que, como disposição complexa de elementos de que o artista dispõe e que transforma a seu gosto, traduz a adequação entre as imposições do mundo da técnica e as imposições do trabalho artístico.

É claro que essa oposição parece conferir a Maugüé uma posição inatual e saudosista, e a Levi-Strauss, uma posição moderna e esclarecida.

No entanto, se abandonando a década de 30 , onde recolhemos este escrito esquecido do jovem Strauss, dermos um salto de vinte e seis anos, para recuperá-lo em 1951, nas entrevistas com Charbonnier, veremos que, em plena maturidade, Levi-Strauss retrocedeu, e aproximou-se curiosamente da posição de Maugüé. Então, a evolução do cubismo já havia terminado e aquilo que em 1935 surgira como conquista positiva da arte moderna, porque a aproximava da arte primitiva, - isto é, o abandono da representação pela significação - passa a ser encarado como uma catástrofe negativa, pois tinha acabado afastando-a do público. E foi por não ter encontrado a sua função coletiva - o seu poder de linguagem - que, segundo Levi-Strauss, o cubismo se viu impelido a desdobrar-se nas maneiras, multiplicando os seus idioletos (Picasso). Foi esse fracasso na comunicação que levou o grande antropólogo a abandonar os velhos amores de mocidade e voltar à pintura figurativa. Ou melhor, a procurar em outra fase da história da arte a síntese entre a representatividade da pintura tradicional e a não representatividade, - isto é, a livre representação dos elementos, de certas disposições, de certos arranjos e aproximações de objetos. Assim, de acordo com as predileções pessoais de 1961, a pintura do futuro deveria ser "uma pintura anedótica e superlativamente figurativa (...) que em vez de tentar fugir completamente deste mundo objetivo, que apesar de tudo, é o único mundo que nos interessa enquanto homens; ou de se contentar plenamente com o mundo objetivo, no qual evolui o homem moderno e que não parece satisfatório 
nem para os sentidos, nem para o espírito, se esforçasse, sem toda a aplicação técnica da pintura a mais tradicional, a reconstituir à nossa volta um universo mais vivível que aquele em que nos encontramos..." - Esta síntese, onde, como na pintura chinesa, o pintor desse da paisagem "uma visão mais ou menos transposta e interpretada", Levi-Strauss encontra, de certo modo, em alguns mestres menores da França do Século 18, por exemplo, nas grandes marinhas de Joseph Vernet. São quadros que representam os portos de mar, e se eles o emocionam profundamente, não é pelas suas qualidades estéticas, mas porque lhe oferecem, diz ele, "o meio de reviver essa relação entre o mar e a terra que ainda existia nessa época, essa instalação humana que não destruía completamente, mas antes acomodava as relações naturais da geologia, da geografia e da vegetação, restituindo assim uma realidade de predileção, um mundo de sonho onde podíamos encontrar refúgio."

A semelhança entre este trecho de Levi-Strauss e o início do ensaio de Jean Maugüé sobre a pintura holandesa é flagrante demais para que tornemos a insistir na aproximação. Ambos refletem uma posição estética da representatividade, extremamente racional, européia - diria mesmo, de uma estética do classicismo - nostálgica dos momentos em que a arte traduziu uma relação harmoniosa do homem com a natureza, em que o trabalho humano se inscrevia sem sofrimento na paisagem.

Mas se Jean Maugüé e Levi-Strauss são essencialmente europeus e assim se mantiveram sempre, apesar da estadia no Brasil, Roger Bastide pode ser considerado desde o momento de sua chegada, em 1938, um brasileiro potencial. Seus primeiros escritos já atestam o esforço admirável de compreensão com que se debruça sobre o país que o acolhe, e é tão diferente do seu. Durante os dezessete anos que vive entre nós, procura informar-se exaustivamente sobre a realidade brasileira, através dos viajantes estrangeiros, dos historiadores, dos sociólogos, dos escritores, da arte em geral. Traduz, com uma modéstia exemplar, Casa Grande e Senzala de Gilberto Freyre. E escreve muito - sobre o que lê e sobre o que vê. A vasta produção jornalística desse período abrange crítica literária, estudos sobre folclore, poesia popular, religiosidade afro-brasileira, barroco... São análises importantes, muitas das quais desenvolvidas, que irão aparecer depois sob forma de livro - como em forma de livro surgirão mais tarde os cursos de estética, ministrados na Faculdade de Filosofia.

E difícil escolher numa produção tão rica alguns exemplos de análise, que nos dêem uma idéia aproximada das suas abordagens 
no campo da arte. Por isso, nesta breve palestra, quase não me reportarei aos livros, que são conhecidos de todos. Procurarei fixar-me, antes, na parte mais provisória de seu pensamento, ora nos escritos curtos e brilhantes com que comparecia na imprensa diária; ora em certos cursos de estética, como aquele sobre o barroco, dado na Faculdade de Filosofia, no segundo semestre de 1940. Encontramos aí observações muito agudas que sugerem o esboço de uma estética da paisagem, dos cartazes, dos salões, da cidade moderna; de uma estética do barroco brasileiro e, mesmo, de uma estética afro-brasileira.

I - O primeiro escrito a que me vou referir é de 1951 e surgiu em $O$ Estado de São Paulo, sob a forma de dois artigos e o título geral de "Uma Estética de São Paulo". A análise aplica-se inicialmente ao cartaz publicitário e à função estética que pode assumir, ao lado da função comercial, quando se distribui, não nos centros urbanos, mas ao longo dos trechos mais insípidos das rodovias. Em seguida se refere ao efeito da velocidade na percepção das massas coloridas, que, só permitindo sínteșes geométricas das impressões, encaminha o artista para as soluções do cubismo e da arte abstrata. E na segunda parte do ensaio que encontramos as idéias mais engenhosas, quando focaliza a estética da cidade vertical.

Para Roger Bastide, o espaço de uma cidade como São Paulo que naquele momento iniciava o surto vertiginoso de seu crescimento - é um espaço vertical. Ora, este espaço está em contradição com a sensibilidade horizontal, descrita por Gilberto Freyre e característica do complexo Casa Grande e Senzala ou Sobrados e Mocambos. Como faz a cidade para acomodar às imposições novas da arquitetura a velha mentalidade? E quais as consequiências dessa acomodação?

Pois na Europa, o prédio de apartamentos corresponde ou traduz, na sua disposição interna, a sociedade estratificada de classes superpostas: no primeiro andar localiza-se a burguesia rica, nos andares intermediários a classe média e nos sótãos os empregados. A estrutura arquitetônica repete, por conseguinte, a estrutura da sociedade: separa os grupos, mostrando que as relações entre a família do patrão e do empregado são profissionais; que este é independente, ama a liberdade, é cioso de suas prerrogativas e está comprometido com a luta de classes.

Mas em São Paulo, ao contrário, o prédio de apartamentos repete a organização horizontal da casa-grande: distribui no mesmo andar os cômodos destinados a patrões e empregados; situa as acomodações dos domésticos ao lado da cozinha, fazendo-as ocupar um 
espaço próximo e dependente. O arranha-céu é, assim, uma espécie de grande monstro anacrônico, que inscreve na paisagem dinâmica a velha e retrógrada estrutura patriarcal.

Mas o conflito arquitetônico pode gerar conflitos mais profundos e difíceis de resolver. Outrora, a casa tinha uma função de refúgio, de proteção, de abrigo; enfim, de volta ao regaço materno, como a concebe Otto Rank. A casa-grande ou o sobrado eram definidos pelas suas paredes grossas, pelas salas que se abriam para os terraços ou para os pátios internos. A habitação voltava-se, pois, para o interior, para o silêncio dos jardins e das lembranças.

O apartamento, ao contrário, devido ao seu caráter moderno, liga-se a outra estética, incompatível com esta estrutura: a estética das aberturas rasgadas, das paredes de vidros que não sugerem anteparos. Assim, a família paulista que se transfere para uma habitação coletiva não muda apenas de casa, mas de estética e de estilo de vida. O seu morador não se sente mais protegido pela espessura das paredes; agora é prisioneiro numa gaiola de vidro onde a antiga intimidade do lar foi substituída pelo devassamento. Por outro lado, inverteu-se a hierarquia do prédio europeu e são os andares mais altos, menos atingidos pelo ruído e menos sujeitos à promiscuidade da rua, que serão preferidos pelas classes economicamente favorecidas.

Há ainda mais: o apartamento é "uma máquina de morar" e as idéias normativas que presidiram à sua fatura são o despojamento, a simplificação, a geometria - enfim, uma visão ascética e hospitalar da moradia. Os arquitetos procuram compensar esta aridez, recuperando um pouco a natureza perdida, através das plantas nos vasos, dos seixos rolados e das raízes com formas insólitas, que espalham à guișa de enfeite. Mas é possível - conclui - que uma transformação tão radical do espaço doméstico leve a uma neurose e acabe abalando a célula familiar.

II - O segundo escrito de que me vou utilizar é o comentário que faz a Salóes e Damas do Segundo Império, de Wanderley Pinho. O aparecimento do livro serve de pretexto para que Roger Bastide discorra sobre a sociologia dos salóes - tema pelo qual tem certa predileção e que irá retomar em Arte e Sociedade.

A seu ver, os salões mundanos, sob a aparência de futilidade, podem ser um excelente instrumento para conhecer o estilo de vida de uma época, a transformação das maneiras, o advento dos gêneros artísticos etc... 
Em primeiro lugar, os salões variam com a estrutura das sociedades, conforme elas sejam centralizadas ou autônomas, de classe dominante recrutada na aristocracia de sangue (Séc. 18), ou na aristocracia de dinheiro (Séc. 19). No Brasil, a vida dos salões liga-se intimamente à ascensão da mulher, que por sua vez é decorrência da concentração da população, do desenvolvimento da vida urbana e da desintegração dos quadros do patriarcalismo rural.

Como a vida dos salóes gira em torno da mulher, implica uma transformação profunda dos costumes e a exaltação da figura feminina. Agora ela não é mais louvada como o esteio do lar, mas como a rainha da festa, onde surge entre as luzes, a música e o esplendor das vestimentas. No Brasil, como em toda a parte, estabelece-se uma relação recíproca entre o romantismo e a vida mundana. Pois se, por um lado, o culto apaixonado da mulher no movimento romântico auxilia a dominação feminina nos salóes e festas mundanas, por outro lado, a dominação feminina fornece ao romantismo o alimento e a matéria que o sustentou. É o prestígio da mulher nos salões que explica uma certa poeșia amorosa; que explica o advento dos pequenos gêneros hoje desaparecidos: como os jogos de sociedade, os versos de circunstância, o desenvolvimento da crônica elegante. É a vida dos salões que impulsiona a evolução do romance e aprofunda a análise psicológica; e - poderíamos acrescentar - explica a curva ascendente que vai de José de Alencar a Machado de Assis.

Em resumo, as idéias expostas por Roger Bastide neste pequeno artigo e em outros momentos - como nas aulas que irão dar origem mais tarde a seu livro Arte e Sociedade - são tão inspiradoras, que devem ser colocadas na base de muitas pesquisas posteriores de estética, realizadas entre nós.

III - Uma das suas contribuições mais importantes ao estudo da arte brasileira, são as análises sobre o barroco, feitas em vários momentos de sua obra e reunidas sobretudo num curso não publicado, que ministrou na Faculdade de Filosofia da Universidade de São Paulo em 1940.

As aulas começavam com um conselho preliminar, que considerava fundamental: nos trabalhos de estética brasileira o estudioso deveria substituir o brilho, às vezes infundado, das hipóteses pela pesquisa minuciosa das fontes: documentos de arquivos, de confrarias religiosas, das atas das câmaras locais - enfim, por toda uma tarefa modesta e paciente que, no entanto, podia esclarecer uma série de problemas. Por exemplo: para se compreender o 
problema complexo da mestiçagem estética (que, a seu ver, regia em grande parte o barroco brasileiro), não nos devíamos apoiar em considerações gerais, mas procurar nos assentamentos quem desenhou o plano do edifício, quem foi escolhido para mestre da construção, onde se foi buscar a mão-de-obra etc. Da mesma forma, era na medida em que se podiam estudar as corporações de ofício, que se conseguiria abordar com mais segurança certos problemas, como a influência do negro ou do mestiço sobre o barroco brasileiro.

Opondo-se à tese romântica e fantasiosa de Keyserling, que atribuía a originalidade do barroco hispano-americano, sobretudo a exuberância da sua decoração, às influências telúricas da flora tropical, Bastide prefere explicar a peculiaridade do barroco brasileiro por fatores diversos:

a) pelas condições econômicas;

b) pela distância da metrópole e dos núcleos populacionais;

c) pelo contacto das raças -

combinando em sua abordagem dois enfoques: o histórico, que traça a evolução da arquitetura brasileira, e o ecológico, que descreve os tipos regionais. A bibliografia de que lançava mão era, para a época, a mais extensa possível e abrangia tanto os grandes teóricos universais do barroco, de Weisbach a Eugênio d'Ors, como os estudiosos do fenômeno brasileiro (José Mariano F.o. Aníbal Matos, Salomão de Vasconcelos, Augusto de Lima Jr., Ribeiro Couto, Manuel Bandeira, Mário de Andrade etc.); as publicações do Serviço do Patrimônio Histórico e Artístico Nacional ou a perspectiva tão pessoal de Robert C. Smith em $O$ Caráter da Arquitetura Colonial no Nordeste.

Como o problema é muito vasto, vamos aludir apenas a dois dos aspectos tratados por Bastide: a caracterização dos dois barrocos brasileiros (o nordestino e o mineiro) e a análise do mito do Aleijadinho.

A) $\mathrm{O}$ despojamento maior das igrejas mineiras - afirma ele não foi intencional, derivando do temperamento seco e reservado dos habitantes da região; resultou antes da escassez do ouro e da distância. Quando as igrejas começaram a cobrir a paisagem montanhosa de Ouro Preto, as minas já se estavam exaurindo. E como era penoso fazer chegar àquela distância, em lombo de burro, os grandes blocos de mármore, que vinham da metrópole e desembarcavam na costa; os construtores tiveram de apelar para o seu gênio improvisador e inventivo. Assim, substituíram aquele ma- 
terial nobre e barroco por outros mais modestos, encontrados na redondeza, como a madeira e a pedra-sabão. É a este fenômeno econômico que o barroco mineiro deve a sua feição peculiar; é dele que derivam a graça rococó da matriz do Carmo - toda de madeira pintada de branco, com leves ornamentos dourađos - e a beleza severa da igreja de São Francisco — onde o portal e os púlpitos do Aleijadinho sugerem, em seu ascetismo, a arte gótica de Klaus Sluter.

B) Mas um outro elemento junta-se ao primeiro, para explicar esta oposição dos dois barrocos brasileiros: a unidade territorial não corresponde, no Centro-sul e no Nordeste, a uma sociedade estruturada de maneira uniforme.

A sociedade no Nordeste é centrífuga, ganglionar, rural, centrada no engenho da cana-de-açúcar e na autoridade independente do patriarca; a sociedade de Minas, no final da época de mineração, é uma sociedade centrípeta, urbana, favorecendo a disseminação de um espírito novo, contestatório, como o que vai caracterizar a Independência. Ora, a diferença destas duas estruturas sociais confere à igreja funções diferentes e deixa marcas diversas na estrutura arquitetônica.

No Nordeste, devido à dispersão populacional, a igreja barroca é levada a recuperar o papel de centro de comunhão (mística, econômica, política) que tivera na Idade Média. Ela é, ao mesmo tempo, a capela, o traço de união entre os senhores de engenho e o salão de festas. Por isso é uma igreja de sacristias. Em Minas, inscrita na vida urbana, a igreja reflete a luta de classes, que se exprime na disputa das confrarias religiosas. É uma igreja de confrarias, de duelos de festas religiosas, com seus cânticos, seu aparato, suas procissões.

Mas a igreja da Bahia não é apenas uma igreja de sacristias, é uma igreja de conventos. Ora, tanto a sua divisão tríplice em capela, pátio e ordem terceira quanto a decoração interna de cada uma destas partes ligam-se a uma concepção filosófica e mística, que foi trazida para o Brasil junto com a igreja barroca: a concepção aristotélico-tomista.

Com efeito, segundo a concepção tomista, a ascensão do cosmos em direção à divindade faz-se através de níveis da realidade, de etapas dos diferentes domínios - domínio da ação prática, da filosofia racional, da teologia - que, mesmo autônomos e conservando o seu caráter original, comunicam-se entre si. Ora, esta concepção se inscreve na própria estrutura arquitetônica; vejamos 
como Roger Bastide a analisa, detalhadamente, no convento de São Francisco da Bahia.

A capela - onde se reza - é rutilante de ouro, movimentada pelos jogos trágicos de luz e sombra; representa um grito exaltado de amor místico, que se eleva em direção ao céu. É o domínio da ação teológica. O pátio - onde se passeia e lê - é penetrado de doçura terrestre, com sua fonte, seus canteiros de flores, arcadas e galerias superpostas. É o domínio da filosofia racional. A ordem terceira - ao mesmo tempo separada e unida ao corpo principal - é, com sua capela menor e seus santos, um recinto onde a prece já perdeu o aspecto místico e de ascetismo e, imbuída dos problemas profanos, aproxima-se das virtudes morais. É o domínio da ação prática.

A decoração dos azulejos repete e sublinha esta divisão tomista de planos do real, que fez com que se considerasse São Tomás o primeiro dos livre-pensadores. Assim, os azulejos da igreja são religiosos e descrevem a majestade do Monarca, senhor absoluto do céu e da terra; mas como concepção e estilo, são barrocos. Os azulejos do pátio são morais e afirmam a existência, abaixo da ética cristã, de uma moral natural, comum a todo ser pensante. $\mathrm{E}$ os azulejos do convento (ordem terceira) são mundanos e representam cenas de gênero - caçadas, passeios pela cidade. Quanto ao estilo, os dois últimos são rococó e já significam, portanto, uma nítida preparação para o romantismo.

Concluindo, Roger Bastide afirma que a estrutura arquitetônica do convento e a sua decoração manifestam com eloquiência o liame que une a filosofia natural de São Tomás de Aquino apoiada em Aristóteles - ao romantismo e, portanto, à natureza instintiva.

A parte final do curso sobre o barroco é dedicada ao problema do Aleijadinho, focalizado sobretudo do ponto de vista das representações coletivas. A seu ver, haveria dois tipos de representações que, recobrindo a vida real do artista, explicavam a lenda que se formara à sua volta: a concepção oriental do artista-místico e a concepção ocidental do artista-herói. Os argumentos de que se serve para apoiar a sua tese são, em resumo, de dois tipos: estéticos e biográficos.

1. A opinião crítica dominante via em Antônio Francisco Lisboa um inovador, um criador de valores estéticos originais, que substituíra a velha igreja retangular brasileira pela igreja curva, barroca, 
borromínica. Se bem que ainda fosse difícil estabelecer um julgamento objetivo - pois haveria necessidade de pesquisar nos arquivos, para estabelecer a ordem de precedência das igrejas borromínicas do Rio e de Minas - Bastide conclui que vários indícios fortaleciam a hipótese de que esse novo tipo de barroco fora importado.

Em primeiro lugar, era um barroco contrário aos modelos portugueses vigentes no Brasil. Portanto não poderia ter derivado dos ensinamentos dos mestres-de-obra contemporâneos ao Aleijadinho e pertencentes todos à tradição portuguesa. Por outro lado, se a igreja curva tivesse nascido espontaneamente no Brasil, encontraríamos, entre o plano inicial retangular e o plano borromínico, formas intermediárias, e não esse contraste brusco e absoluto. Aliás, a utilização da linha curva na arquitetura não tinha apenas uma explicação estética, pois derivava das transformações da matemática, sendo por conseguinte um fenômeno tipicamente europeu que não poderia valer para o Brasil. Não era possível, portanto, menosprezar a influência européia, muito mais poderosa que a do meio brasileiro - sobretudo tendo em vista o hábito corrente na época de importar da Europa os planos já prontos das igrejas (riscos). A conclusão final de Bastide é que não só era impossível atribuir ao Aleijadinho a criação de um novo barroco, como a solução que ele havia encontrado representava na verdade um retrocesso na evolução geral da arte brasileira: era a tentativa de adaptar um estilo desconhecido na colônia à igreja retangular tradicional. Essa contradição é que explicava, aliás, as formas híbridas que encontramos em algumas de suas obras, como a fachada da igreja de São Francisco, combinação de linhas curvas e formas retangulares. Nesta perspectiva, o que se tomava como inovação do artista representava, no fundo, um desejo de não se afastar excessivamente da tradição.

2. Mas é sobretudo na análise da biografia do Aleijadinho que Roger Bastide vê delinearem-se com mais nitidez os traços da lenda. Com efeito, as narrativas de sua vida o descrevem como filho natural, marcado pela cor e pela feiúra, sem instrução, valendo apenas pela força da inspiração, e - sobretudo - estigmatizado pela doença. Esta o teria feito perder os dedos dos pés, o polegar, o índex, os dentes, as pálpebras; o teria transformado num monstro, que trabalhava escondido, envolto numa capa preta, com o camartelo amarrado à mão. 
Ora, comenta Bastide, todos os elementos dessa biografia transpiram a lenda e são fáceis de destruir. É falso que o Aleijadinho fosse ignorante: a utilização de certas técnicas eruditas, como a do medalhão, ou a escolha dos profetas do adro de Congonhas, desmentem a idéia de um artista inculto. Da mesma forma, a boa caligrafia dos autógrafos, encontrados nos contratos e recibos, quando já tinha perto de sessenta e seis anos, afasta a hipótese de que não tivesse dedos. Enfim, as lendas que correm sobre a sua vida são análogas às que circulam sobre tantos outros artistas e nelas vemos superpor-se, como já dissemos no início, a concepção do artista-místico e do artista-herói. Aliás, ao lado do mito do Aleijadinho seria possível apontar, ainda, na imagem dos dois escravos, Agostinho e Januário, que o serviam com abnegação, a lenda do bom escravo.

IV - Mas uma visão, mesmo fragmentária, como a que estou procurando apresentar, dos estudos de estética de Roger Bastide, seria falsa e incompleta se não se referisse à contribuição que trouxe ao estabelecimento de uma estética afro-brasileira. Portanto, abandonando agora as análises admiráveis que dedicou ao nosso barroco, vou adotar outra perspectiva: isto é, referir-me a certos estudos menos conhecidos, enfeixados sob o título "Ensaio Sobre uma Estética Afro-Brasileira", publicado em seis partes em $O$ Estado de São Paulo, em fins de 1947 e inícios de 1948. Esta tentativa de demonstrar a relação existente entre algumas manifestações estéticas do candomblé baiano e as categorias do pensamento místico, constitui talvez a contribuição mais curiosa da meditação estética do nosso autor.

A idéia central do ensaio, exposta na primeira parte, é que o pensamento místico apresenta uma estrutura dualística básica que, manifestando-se nas religiões mais diversas, também caracteriza o pensamento afro-brasileiro e se revela numa série de manifestações do candomblé, como nas danças rituais dos orixás.

A primeira impressão dada pelo candomblé, de que os orixás são múltiplos (há vários Xangôs, vários Oguns, vários Exus provavelmente em conseqüência da diversidade das tribos importadas), não deve ser tomada ao pé da letra. $\mathrm{O}$ exame atento do fenômeno irá demonstrar que sob a massa das divindades, tendem a predominar sempre dois orixás privilegiados: o velho e o moço. O problema é saber donde se originou essa duplicação, que cinde os orixás em entidades distintas, caracterizando cada um por uma linha melódica própria, por uma determinada equivalência católica e mesmo por cores distintivas especiais. 
A primeira hipótese é que o dualismo derivaria da influência católica. E isso, por várias razões. Um dos orixás mais populares é Oxalá, que no processo de aculturação é identificado a Jesus Cristo e se subdivide, como os demais, em Oxalá Moço e Oxalá Velho. Ora, apesar de ter morrido com trinta e três anos, Jesus Cristo também é conhecido no candomblé como o Velhão. Um outro elemento reforçaria o anterior: a história da vida de Cristo, tal como vem narrada nos Evangelhos, expressa nas imagens e conservada na representação popular, refere-se apenas a duas fases: a infância, onde Jesus surge sob a forma de um menino, no colo da Virgem, e a idade adulta, onde é representado ora entre os apóstolos ora na tragédia do Calvário. Esta oposição entre um Cristo-menino e um Cristo-homem é que estaria na base da oposição Oxalá-Moço/Oxalá-Velho, daí difundindo-se para os demais orixás.

No entanto, sem rejeitar a possibilidade do contato de culturas ter conferido à oposição matizes originais, Roger Bastide prefere aceitar o dualismo como um fenômeno universal, "uma exigência do pensamento místico, uma lei geral da estrutura do sagrado".

O método comparativo pode auxiliar a entender como a bipolaridade é um impulso estético-religioso; por isso Bastide aproxima o candomblé da mitologia grega, que a seu ver fornece excelentes exemplos desse processo. Por exemplo:

a) Baco, deus do vinho, é representado sob dois aspectos: uma criança e um velho bêbado; ou como o Baco triunfante da juventude e Sileno, o velho decrépito, encarapitado no burro;

b) outras vezes o dualismo pode afetar a forma de desdobramento, como, por exemplo, quando a mesma divindade se personifica em divindades de idades diferentes: é o caso da Terra, que pode-se desdobrar em Deméter (a Mãe) e Coré (a Filha); ou quando a mesma divindade assume aspectos opostos: é o caso da Lua, que sob o seu aspecto bom é adorada como Artêmis e, sob seu aspecto mau, como Hécate.

Ora, a peculiaridade do candomblé é que ele reproduz esse impulso estético-religioso, conservando toda a frescura do concreto e da observação do real, característica da mentalidade africana. estilo realista, familiar, cheio de pormenores, das duas idades é apreendido ao vivo: por exemplo, no andar trôpego do velho curvo, ou no ar brincalhão e alegre da criança. A dança funde a seriedade do ritual religioso com a comicidade do jogo, pois a mentalidade mística não separa, como a ocidental, o território do sa- 
grado e o da diversão. E mesmo que em seu desenrolar se entregue a uma emoção puramente lúdica, mesmo assim permanece uma dança religiosa, reflexo da bipolaridade mística.

Pode-se afirmar, por conseguinte que, independentemente das particularidades culturais, a bipolaridade é uma exigência estrutural da mentalidade mística. Aliás Frobenius — um dos que melhor estudou a mentalidade africana — e os psicanalistas da escola de Jung, já haviam constatado a sua universalidade, ao encontrarem nos sonhos dos africanos os mesmos mitos da Grécia (por exemplo, o de Electra). Daí ser possível admitir certo número de representações comuns, uma espécie de quadro geral das categorias ao mesmo tempo estéticas e religiosas - bem diversas das categorias kantianas - que acolhem e plasmam as emoções elementares, as quais, surgidas das camadas subterrâneas mais sagradas, cristalizam-șe nos ritos e na arte. Religião e arte seriam, dessa maneira, o reflexo daquilo que Frobenius chamou de consciência paideumática. $\mathrm{E}$ da mesma forma que o entendimento se divide em categorias, o paideuma possui uma estrutura: a bipolaridade seria uma dessas estruturas paideumáticas básicas e corresponderia, em última análise, à distinção $\mathrm{Eu}$ e Tu, ou Si Mesmo e Outro.

A segunda parte do ensaio é dedicada à análise dos pontos riscados, que constituem uma forma de representação gráfica da divindade, feita no chão do terreiro, junto ao poste central. Usando uma analogia grosseira, eu diria que os pontos riscados correspondem ao que são, na sociedade de consumo, as marcas industriais. São a maneira gráfica de evocar o orixá, como os cantos são o seu leitmotiv melódico, a dança o seu leitmotiv gestual e assim por diante.

No Vodu haitiano os pontos riscados (vévés) são esteticamente muito mais ricos e elaborados. Sofreram a influência do trabalho de ferro batido dos negros que, fundindo os símbolos daomeanos à preciosa arte rococó de Luís XV, conseguiram uma arte encantadora. $\mathrm{O}$ indianismo da macumba não pode alcançar a mesma perfeição, por causa das condições diferentes do trabalho africano no Brasil. No Haiti houve uma coincidência feliz entre a cristalização da tradição vodu, a época do artesanato e o período rococó; mas no Brasil, os pontos riscados só assumiram a sua forma definitiva no Século 19, portanto, num período de decadência artística, quando o negro estava mergulhado no operariado e já se estabelecera o divórcio entre a beleza e o trabalho.

Os pontos riscados podem apresentar-se em combinações simples e complexas. As primeiras, são os pontos particulares de cada 
espírito. Nelas a imaginação trabalha um pouco ao sabor das associações, recorrendo à vida interior, aos recursos retirados da estrutura do inconsciente. As segundas combinam vários pontos simples, visando a um efeito mágico qualquer. A imaginação, neste caso, é sustentada por apoios externos, sólidos, recorrendo à vida social.

Em ambos os casos, os elementos de que o babalaô se serve são pouco numerosos: flechas, cruzes, estrelas etc., o que o obriga a demonstrar nos arranjos a sua capacidade inventiva. Por outro lado, como as combinações devem ser apreendidas rapidamente, devem ser fáceis de desenhar e de memorizar, têm de organizar-se de acordo com a boa forma (gestalt), isto é, esteticamente.

A hipótese de Roger Bastide é que, ao arranjar livremente os elementos do desenho num conjunto harmonioso, o babalaô se deixa guiar pela estrutura mística do espírito, a qual faz brotar das profundezas do $\mathrm{Eu}$, o que Jung chamaria de arquétipos.

\section{Primeiro exemplo:}

Frequientemente os elementos dos pontos riscados se organizam para formar uma estrutura estrelada, de raios múltiplos. Ora, o que logo chama a atenção, é que a linha central da estrela de cinco pontas é horizontal e não vertical:

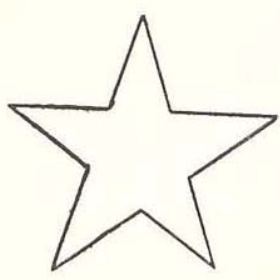

Sim

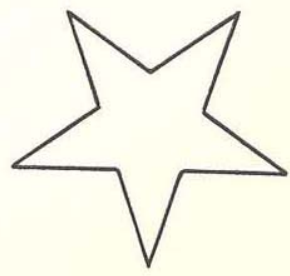

Não

Qual a explicação dada por Bastide? O espírito apreende de maneira mais ou menos consciente - diz ele - que a mitologia afro-indiana se situa no plano da manifestação e não na linha que liga Deus ao Cosmos. Que se trata, portanto, de demonstração do Divino e não de emanação. Dessa forma, as tendências esté- 
ticas, expressas pela estrutura dos pontos, revelam sentimentos interiores profundos, que atingem o domínio do sagrado.

\section{Segundo exemplo:}

$\mathrm{Na}$ maioria dos pontos, os elementos que os compõem - flechas, lanças, espadas - apresentam as pontas voltadas para baixo:

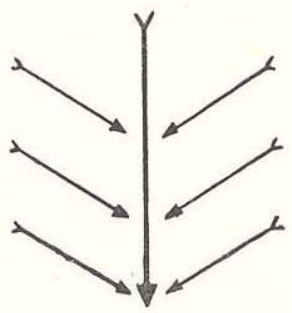

Caboclo sete flechas

Roger Bastide acredita que, ao traçar os pontos o babalaô se deixou levar por uma penetração muito justa, embora inconsciente, que assinala a diferença entre a mística cristã e a afro-brasileira. A primeira, caracteriza-se pelo esforço de subir até Deus e perder-se na Unidade; a segunda, é a mística da descida dos deuses nos homens, como aliás atesta o termo corrente no candomblé, de descida de santo. O movimento para baixo indica a direção de descida fluídica, de visitação do divino no mundo corporal.

\section{Terceiro exemplo:}

$\mathrm{Na}$ maioria dos pontos de Exu, aparece o tridente. Mas por que o tridente, emblema das divindades do mar, quando Exu é uma divindade da terra? Porque Exu também é o deus da orientação, dos caminhos, das encruzilhadas e na África é representado por um elemento em forma de cone, significando o mastro que liga o céu e a terra. Ora, essa coluna que liga o céu à terra reaparece no candomblé da Bahia sob a forma de mourão central e nada mais é que a sobrevivência da árvore da vida do Gênese - a qual é desenhada tradicionalmente com três ramos e três raízes, estas últimas vistas como o reflexo invertido das primeiras. Deste modo, o tridente de Exu, com seus três ramos terminais e seu punho com 
três pontas menores, sugere-nos imediatamente a árvore do mundo, da vida ou da morte.

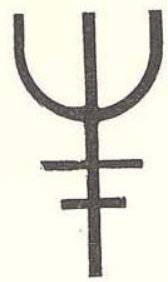

Ponto de Exu

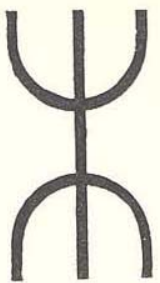

Árvore do Mundo

Portanto, conclui Roger Bastide, a estrutura paideumática da mística do Cosmos, que os antigos iorubas preservam até hoje na África, sobrevive entre nós na mentalidade popular brasileira.

E chego, não sem tempo, ao fim de minha exposição.

Os três professores que eu quis rememorar nesta aula, representam um período arqueológico do ensino da filosofia, quando ainda não existíamos como departamento e o currículo, muito mais flexível, possibilitava a união híbrida de disciplinas bem díspares. Por isso não é de estranhar que, através de um percurso longo e caprichoso, eu os tenha feito circular da Europa para o Brasil, do Brasil à África, da Estética à Sociologia. Levados pelas preferências artísticas destes três mestres, passamos, sem muito escrúpulo, de certas formas muito altas da arte do Ocidente - como a pintura e a arquitetura - às mais rudimentares - como a dança ritual dos orixás e os pontos riscados do candomblé. Pois se Mauguié e Levi-Strauss têm nesse período um ponto de referência exclusivo, a Europa, e mesmo as épocas de maior requinte e racionalidade, como os Séculos 17 e 18, Roger Bastide prefere voltar sua atenção para as culturas chamadas primitivas, as manifestações estético-religiosas e os problemas de mestiçagem artística.

A intenção inicial desta palestra foi, fixando-me no campo da Arte, lembrar, a um público muito posterior, - e portanto, naturalmente, ignorante da história miúda da nossa universidade - a importância que esses três professores tiveram na formação da minha geração. Vejo, no entanto, que, embora sem querer, acabei traçando, de maneira canhestra e esquemática, o próprio impasse em 
que se encontra a Estética moderna - impasse que esses três mestres exemplificam, através de suas preferências, idiossincrasias e perplexidades.

A meditação de Maugüé e Levi-Strauss continua, como já afirmei, presa à Estética da representação e ao prestígio reconhecido da Razão; centrada sobre a pintura, e destacando como mais perfeitos certos momentos da sua história, supõe uma hierarquia das artes e um ideal absoluto de beleza. É, de certo modo, uma estética hegeliana e, por conseguinte, do passado. É essa a razão pela qual terminam ambos, como que a contragosto, rejeitando as manifestações mais vivas da vanguarda; rejeitando a avalanche irreprimível que, iniciada pelo impressionismo e pela incorporação das pesquisas espaciais do Oriente, é levada adiante por Gauguin, com seu desprezo à Grécia, para receber o golpe de graça de Picasso, quando este descobre as máscaras africanas.

Em oposição à Estética do classicismo de Jean Maugüé e Levi-Strauss, as análises de Roger Bastide giram em torno de outro conceito de arte. Já é sintomático que, dentre as manifestações estéticas do Século 17, vá preferir o movimento que, aos olhos tranqüilos dos franceses, pode surgir como uma exceção: o cataclismo irracional do barroco. E que, ao barroco europeu, apesar de tudo já reconhecido pela crítica, prefira a feição peculiar que este estilo de corte assume na colônia, quando o meio pobre e a mestiçagem dos artistas the imprimem tantas deformações. A sua estética é pois uma estética de antropólogo, de estudioso dos fenômenos de misticismo religioso.

Mas é também uma estética de vanguarda. Na extrema mocidade Bastide passou pelo crivo do dadaísmo e do surrealismo, pelas experiências radicais que questionaram, para toda a posteridade, os valores eternos da obra de arte. Era natural pois que, chegando a um país sem grande tradição cultural, se tivesse dedicado à elaboração de uma estética pobre - usando o termo em analogia com o que hoje se costuma designar por arte pobre — isto é, uma estética que, voltando as costas para os grandes períodos e as grandes manifestações artísticas, fosse desentranhar o fenômeno estético do cotidiano, dos fatos insignificantes e sem foros de grandeza, que compõem, no entanto, o tecido de nossa vida. Uma estética, enfim, que não se preocupando com a obra de arte - muito menos com a obra-prima -, tentasse surpreender de que modo se revelava, através de certas categorias, como o pensamento místico, uma das formas mais válidas e mais altas do conhecimento. 